\title{
Layanan informasi berbasis self-compassion untuk mereduksi body dissatisfaction pada siswa perempuan
}

\author{
Rafika Andreana Putri ${ }^{1}$, Evi Fitriyanti ${ }^{*}$, , Burhanudin Burhanudin ${ }^{3)}$ \\ 1,2,3) Universitas Indraprasta PGRI \\ *) ibukevifitriyanti.21@gmail.com
}

Article History: Received: 08/04/2021; Revised: 17/05/2021; Accepted: 11/06/2021; Published: 28/06/2021.

How to cite: Putri, R.A., Fitriyanti, E., \& Burhanudin, B. (2021). Layanan informasi berbasis self-compassion untuk mereduksi body dissatisfaction pada siswa perempuan. Orien: Cakrawal Ilmiah Mahasiswa, 1(1), pp. 59-66 DOI: 10.30998/ocim.v1i1.4573

\section{(c) (i) This is an open} distributed under the Creative Commons 4.0 Attribution License, which permits unrestricted use, distribution, and reproduction in any medium, provided the original work is properly cited. (c) 2021, Putri, R.A., Fitriyanti, E., \& Burhanudin, B.

\begin{abstract}
Abstrak: Penelitian ini bertujuan untuk mengetahui pengaruh layanan informasi berbasis self-compassion untuk mereduksi body dissatisfaction pada siswa. Penelitian ini merupakan penelitian kuantitatif dengan jenis survei. Sampel penelitian ini adalah 77 siswa perempuan yang diambil secara acak. Data pada penelitian ini dikumpulkan melalui teknik angket. Data dianalisis dengan menggunakan teknik regresi linier sederhana. Hasil penelitian ini adalah layanan informasi berbasis self compassion mampu mereduksi body dissatisfaction pada siswa perempuan.
\end{abstract}

Kata Kunci: layanan informasi, self-compassion, body dissatisfaction

Abstract: This study aimed to determine whether information service based selfcompassion could to reducting students body dissatisfaction. This was a quantitative research with survey method. Samples in this study amounted to 77 students that taken randomly. Data were colletcted by questionnaire technique. Data were analyzed by simple regression linier test. The result shown that information service based self-compassion effective to reducting students body dissatisfaction.

Keywords: information service, self-compassion, body dissatisfaction

\section{Pendahuluan}

Masa remaja merupakan salah satu fase perkembangan terpenting yang ditandai dengan adanya periode peralihan dan perubahan. Pada masa remaja, seseorang akan banyak mengalami perubahan, baik secara fisik maupun psikis. Siswa dengan tugas perkembangan remaja pada tingkat SMA sederajat banyak mengalami perubahan melalui kondisi pubertas. Kusumawati, dkk (2018) menjelaskan bahwa pubertas ialah suatu periode dimana kematangan kerangka dan seksual terjadi dengan pesat terutama pada awal masa remaja. Kematangan seksual merupakan suatu rangkaian dari perubahan-perubahan yang terjadi pada masa remaja, yang ditandai dengan perubahan pada seks primer (primary sex characteristics) dan perubahan pada seks sekunder (secondary sex characteristics).

Berdasarkan kondisi pubertas yang dialami oleh siswa di masa remaja, banyak terjadi perubahan fisiologis dalam skala besar dimana mereka mengalami peningkatan seperti tinggi badan, berat badan dan kekuatan, berkembang secara seksual, dan mengalami perubahan dalam penampilannya. Berbagai perubahan tersebut terjadi dalam periode waktu tertentu, tentunya sesuai dengan usia dan keadaan hormon yang berbeda-beda pada siswa yang satu dengan lainnya. Akibatnya tidak sedikit siswa yang merasa malu, sangat tidak nyaman atas kondisi 
dirinya, gelisah dan bingung bersikap dengan teman sebaya dimana dirinya merasa mengalami perbedaan perkembangan dengan teman-temannya. Oleh karena itu, banyak siswa yang mengalami sikap rendah diri dan juga body dissatisfaction terhadap penampilan dirinya. Istilah body dissatisfaction merupakan ketidakpuasan terhadap penampilan tubuh serta merupakan perasaan dan pemikiran negatif seseorang terhadap tubuhnya (Grogan, 2008) dalam (Kurnia \& Lestari, 2020). Body dissatisfaction terjadi ketika ada kesenjangan antara persepsi bentuk tubuh ideal seseorang dengan bentuk tubuh mereka sebenarnya (Niide, Davis, Tse, Derauf, Harrigan, \& Yates, 2011). Penelitian dari Yuanita dan Sukamto (2013) terhadap 150 perempuan menemukan bahwa $74 \%$ remaja perempuan dan $52 \%$ perempuan dewasa awal mengalami body dissatisfaction dengan kategori tinggi akibat perubahan bentuk fisik yang tidak sesuai dengan standar ideal.

Siswoariwibowo dkk (2020) menyatakan bahwa salah satu faktor utama terjadinya body dissatisfaction adalah berat badan, tetapi terdapat beberapa faktor lain yang menyertai seperti warna kulit, bentuk hidung, ukuran payudara dan sebagainya. Faktor lain penyebab terjadinya body dissatisfaction pada perempuan adalah faktor sosial (tekanan sosial budaya) dan faktor biologis. Tekanan sosial budaya dari berbagai sumber, seperti keluarga dan lingkungan sebaya, memberikan tekanan-tekanan atau dorongan untuk menjadi langsing sesuai dengan standar ideal perempuan di masyarakat (Paxton, Eisenberg, \& Sztainer, 2006) dalam (Yuanita \& Sukamto, 2013). Faktor biologis yang menyebabkan terjadinya body dissatisfaction pada perempuan salah satunya adalah perubahan fisik yang terjadi terkait pubertas, seperti timbulnya haid, dapat menumbuhkan perasaan malu karena budaya berasumsi bahwa perempuan haid lebih memancarkan pesan-pesan negatif, dan hal ini membuat perempuan merasa jauh dari standar ideal kecantikan (Giaber et al, dalam Stice \& Whitenton, 2002).

Faktor penyebab terjadinya body dissatisfaction, yang mencakup standar kecantikan yang tidak tercapai, ketidakpuasan yang mendalam terhadap diri sendiri, dan individu hidup dalam budaya first impression atau kesan pertama. Body dissatisfaction seringkali dikaitkan dengan rasa tidak percaya diri ketika berhubungan dengan lawan jenis dan juga orang lain (Ackard, KearneyCooke, \& Peterson, 2000) dalam (Kurnia \& Lestari, 2020). Body dissatisfaction dapat menyebabkan beberapa kondisi psikologis lain seperti suasana hati yang depresif, kecemasan, kecemasan sosial akibat kondisi fisik dan fobia sosial (Tariq \& Ijaz, 2015). Kesenjangan yang terjadi mengenai persepsi atau standar kecantikan yang sering disalahartikan menyebabkan berbagai dampak negatif bagi kondisi psikis yang mana akan banyak individu yang insecure terhadap tubuhnya. Dampak negatif lain yang terjadi adalah individu akan mudah merasa rendah diri dan cemas dan jika tidak diatasi akan mengarah dalam kondisi depresi Asih, 2002 (dalam Siswoariwibowo dkk, 2020).

Apabila siswa yang mengalami kondisi body dissatisfaction hanya memendam perasaannya sendiri tanpa adanya bantuan yang diterimanya maka tentunya banyak sekali permasalahan yang akan muncul selanjutnya, yang menjadikan kehidupan efektif sehari-harinya terganggu. Salah satu bantuan yang dapat di terima oleh siswa adalah melalui layanan informasi berbasis self-compassion. Dalam hal ini, layanan informasi berupaya untuk memenuhi kebutuhan individu yaitu siswa sebagai remaja akan informasi yang diperlukannya, terutama dalam kaitannya dengan kondisi body dissatisfaction yang sedang dialami, dimana melalui layanan ini akan disampaikan berbagai informasi yang dibutuhkan oleh individu sebagai peserta layanan yang kemudian informasi tersebut diolah dan dipergunakan untuk kepentingan kehidupan dan juga kemampuan positif individu yang bersangkutan (Evi dkk, 2017). Keterkaitannya adalah, layanan informasi hadir untuk memenuhi kebutuhan akan informasi yang dibutuhkan oleh individu yang memerlukan informasi. Diperlukannya informasi bagi individu adalah penting, 
mengingat kegunaan informasi yang didapatkan sebagai acuan untuk bersikap dan bertingkah laku sehari-hari, sebagai pertimbangan arah pengembangan diri, serta sebagai dasar pertimbangan dalam mengambil keputusan (Evi, 2018).

Self-compassion merupakan salah satu bahasan yang dapat menjelaskan bagaimana individu mampu bertahan, memahami dan menyadari makna dari sebuah kesulitan sebagai hal yang positif (Hasanah \& Hidayati, 2017). Neff (2003) dalam (Hidayati, 2016) menambahkan bahwa self-compassion adalah proses pemahaman tanpa kritik terhadap penderitaan, kegagalan atau ketidakmampuan diri dengan cara memahami bahwa ketiga hal tersebut merupakan bagian dari pengalaman sebagai manusia pada umumnya. Self-compassion penting dimilki oleh remaja karena dapat membantu remaja untuk mengatasi berbagai masalah kehidupannya. Fungsi dari self-compassion adalah sebagai strategi beradaptasi untuk menata emosi dengan cara menurunkan emosi negatif serta meningkatkan emosi positif berupa kebaikan dan hubungan (Akin, 2010).

Banyak manfaat atau nilai positif dari self-compassion, berdasarkan penelitian Breines \& Chen (2012) mengungkapkan bahwa orang-orang yang menggunakan self-compassion dalam menghadapi kelemahan diri memiliki motivasi yang besar untuk meningkatkan dan mengubah perilaku menjadi lebih baik. Self-compassion juga menjadi penolong untuk lebih meringankan rasa terpuruk sehingga individu akan menjadi lebih terbuka pada kegagalan atau masalah yang dialaminya. Self-compassion dapat membantu individu lebih mengenal dirinya sendiri, lebih menyayangi dirinya sendiri, sehingga akan mempermudah individu dalam menghadapi kesulitan yang sedang dialami. Apabila sudah dapat terbuka dengan masalah yang tengah dihadapinya, maka individu cenderung akan terbuka juga dengan lingkungan sekitarnya atau orang lain. Individu akan menjadi berani untuk menceritakan atau berbagi pengalamannya kepada orang lain, sehingga individu dapat dengan mudah membentuk hubungan yang bermakna dengan orang lain. Ketika hubungan bermakna dengan orang lain terbentuk, individu akan terhindar dari perasaan terasing atau alienasi.

Penelitian ini bertujuan untuk mengetahui pengaruh layanan informasi berbasis selfcompassion untuk mereduksi body dissatisfaction pada siswa perempuan. Hasil penelitian ini diharapkan dapat memperkaya khazanah ilmu pengetahuan bimbingan dan konseling khususnya di bidang konselng perkembangan peserta didik serta menjadi referensi tambahan mengenai faktor-faktor yang mempengaruhi perilaku body dissatisfaction pada siswa. Hipotesis yang diajukan dalam penelitian ini adalah terdapat pengaruh layanan informasi berbasis selfcompassion untuk mereduksi body dissatisfaction pada siswa perempuan.

\section{Metode}

Penelitian ini menggunakan pendekatan kuantitatif dengan metode survei bertujuan untuk mengukur pengaruh layanan informasi berbasis self-compassion untuk mereduksi body dissatisfaction pada siswa perempuan di SMK Mardi Bakti Jakarta Timur. Dimana sebelumnya para siswa perempuan sudah mendapatkan layanan informasi berbasis self-compassion terkait dengan kondisi body dissatisfaction yang dialami oleh siswa perempuan di sekolah tersebut dimana layanan Informasi tersebut sudah diberikan oleh guru Bimbingan dan Konseling.

Populasi terjangkau dari penelitian ini adalah siswa perempuan kelas X dan XI di SMK Mardi Bakti Cijantung, Jakarta Timur yang berjumlah 96 siswa. Teknik pengambilan sampel yang akan digunakan dalam penelitian ini adalah random sampling atau dilakukan secara acak. Dari jumlah populasi yang berjumlah 96 orang siswi, maka sampel di dalam penelitian ini adalah sebanyak 77 orang siswa perempuan yang di tentukan melalui perhitungan teknik Slovin. 
Pengumpulan data di dalam penelitian ini menggunakan angket skala likert, dimana sebelumnya sudah dilakukan uji validitas menggunakan program winsteps dan juga pegukuran reliabilitas menggunakan aplikasi komputer winsteps ranch. Angket yang telah valid dan reliabel disebarkan kepada responden melalui google formulir untuk memudahkan pengumpulan data di masa pandemi covid-19.

Pengambilan data penelitian di lakukan pada tanggal 18 Juni 2020. Data yang telah diperoleh untuk kemudian dilakukan perhitungan regresi linear sederhana didasarkan pada hubungan fungsional atau kausal satu variable bebas dengan satu variable terikat. Persamaan umum regresi linear sederhana adalah $\hat{Y}=a+b X$. Regresi adalah proses identifikasi relasi dan pengaruhnya pada nilai-nilai objek. Regresi bertutjuan menemukan suatu fungsi yang memodelkan data dengan meminimalkan galat atau selisuh antara nilai prediksi dengan nilai sebenar nya (Jayanti, 2020). Dan di dalam penelitian ini menggunakan Uji hipotesis dengan F-test yang digunakan untuk menguji hubungan dua variabel bebas secara bersama-sama dengan variabel terikat, (Sureiman \& Mangera, 2020).

\section{Hasil dan Diskusi}

Penelitian ini terdiri dari dua variabel, yaitu variabel layanan informasi berbasis selfcompassion sebagai variabel bebas dan variabel body dissatisfaction sebagai variabel terikat. Penulis menyajikan deskripsi hasil penelitian variabilitas dari kedua variabel penelitian ini yang mencakup skor tertinggi, skor terendah, simpangan baku, modus, median, dan sebaran data, sebagai dasar untuk pembahasan selanjutnya. Deskripsi data penelitian setiap variabel adalah sebagai berikut:

\section{a. Deskripsi self-compassion siswa}

Berdasarkan hasil perhitungan SPSS versi 25 diperoleh deskripsi data variabel selfcompassion sebagai berikut:

Tabel 1. Statistics Self-Compassion

\begin{tabular}{|c|c|}
\hline \multicolumn{2}{|c|}{ Statistics } \\
\hline \multicolumn{2}{|c|}{ Layanan Informasi berbasis self-compassion } \\
\hline Valid & 77 \\
\hline Missing & 0 \\
\hline Mean & 108.91 \\
\hline Std. Error of Mean & 1.138 \\
\hline Median & 110.00 \\
\hline Std. Deviation & 9.987 \\
\hline Variance & 99.742 \\
\hline Range & 45 \\
\hline Minimum & 90 \\
\hline Махітum & 135 \\
\hline
\end{tabular}

Sumber: Diolah dari data penelitian, 2021

Skor self-compassion yang diperoleh dari responden mempunyai rata-rata 108,91 dengan simpangan baku 9,987, median sebesar 110,00, skor minimum 90 dan skor maksimum 135 . Hal ini menunjukkan bahwa rata-rata skor self-compassion termasuk tinggi. Skor simpangan baku 9.987 atau 10,9\% dari total rata-rata, hal ini menunjukkan perbedaan jawaban antar responden termasuk tinggi. Hal ini menunjukkan bahwa self compassion dari responden cukup beragam dan temasuk positif. Berikut disajikan frekuensi variabel self compassion. 
Tabel 2. Distribusi Frekuensi Variabel X

\begin{tabular}{|c|c|c|c|c|c|}
\hline & & \multicolumn{3}{|c|}{ Self-Compassion } & \multirow[b]{2}{*}{ Cumulative Percent } \\
\hline & & Frequency & Percent & Valid Percent & \\
\hline \multirow{32}{*}{ Valid } & 90 & 1 & 1.3 & 1.3 & 1.3 \\
\hline & 93 & 2 & 2.6 & 2.6 & 3.9 \\
\hline & 94 & 7 & 9.1 & 9.1 & 13.0 \\
\hline & 95 & 1 & 1.3 & 1.3 & 14.3 \\
\hline & 97 & 4 & 5.2 & 5.2 & 19.5 \\
\hline & 98 & 2 & 2.6 & 2.6 & 22.1 \\
\hline & 99 & 1 & 1.3 & 1.3 & 23.4 \\
\hline & 100 & 3 & 3.9 & 3.9 & 27.3 \\
\hline & 101 & 3 & 3.9 & 3.9 & 31.2 \\
\hline & 102 & 1 & 1.3 & 1.3 & 32.5 \\
\hline & 105 & 1 & 1.3 & 1.3 & 33.8 \\
\hline & 106 & 2 & 2.6 & 2.6 & 36.4 \\
\hline & 107 & 1 & 1.3 & 1.3 & 37.7 \\
\hline & 108 & 2 & 2.6 & 2.6 & 40.3 \\
\hline & 109 & 2 & 2.6 & 2.6 & 42.9 \\
\hline & 110 & 6 & 7.8 & 7.8 & 50.6 \\
\hline & 111 & 1 & 1.3 & 1.3 & 51.9 \\
\hline & 112 & 3 & 3.9 & 3.9 & 55.8 \\
\hline & 113 & 5 & 6.5 & 6.5 & 62.3 \\
\hline & 114 & 7 & 9.1 & 9.1 & 71.4 \\
\hline & 115 & 2 & 2.6 & 2.6 & 74.0 \\
\hline & 116 & 2 & 2.6 & 2.6 & 76.6 \\
\hline & 117 & 4 & 5.2 & 5.2 & 81.8 \\
\hline & 118 & 4 & 5.2 & 5.2 & 87.0 \\
\hline & 119 & 1 & 1.3 & 1.3 & 88.3 \\
\hline & 120 & 2 & 2.6 & 2.6 & 90.9 \\
\hline & 121 & 2 & 2.6 & 2.6 & 93.5 \\
\hline & 122 & 1 & 1.3 & 1.3 & 94.8 \\
\hline & 125 & 1 & 1.3 & 1.3 & 96.1 \\
\hline & 128 & 2 & 2.6 & 2.6 & 98.7 \\
\hline & 135 & 1 & 1.3 & 1.3 & 100.0 \\
\hline & Total & 77 & 100.0 & 100.0 & \\
\hline
\end{tabular}

Sumber: Diolah dari data penelitian, 2021

Dari distribusi frekuensi juga dapat diketahui skor yang berada di atas rata-rata 50,6\%, sedangkan yang berada di bawah rata-rata $42,9 \%$ dengan demikian diartikan skor yang berada di atas rata-rata lebih banyak dibanding yang berada di bawah rata-rata, menunjukkan bahwa siswa yang mempunyai self compassion tinggi, lebih banyak dibanding yang rendah. Berdasarkan tabel distribusi dapat disimpulkan bahwa data skor self-compassion siswa perempuan kelas $\mathrm{X}$ dan XI SMK Mardi Bakti Jakarta Timur termasuk kategori stabil atau cukup baik.

\section{b. Deskripsi body dissatisfaction siswa}

Berdasarkan hasil perhitungan SPSS versi 25 diperoleh deskripsi data variabel body dissatisfaction sebagai berikut: 
64 Layanan informasi berbasis self-compassion untuk mereduksi body dissatisfaction pada siswa perempuan

Tabel 3. Statistics body dissatisfaction

\begin{tabular}{lcc}
\hline \multicolumn{2}{c}{ Statistics } \\
\hline \multicolumn{2}{c}{ Body dissatisfaction } \\
& Valid & 77 \\
Mean & Missing & 0 \\
Std. Error of Mean & 103.16 \\
Median & .903 \\
Std. Deviation & 102.00 \\
Variance & 7.927 \\
Range & 62.844 \\
Minimum & 36 \\
Maximum & 86 \\
Sum & 122 \\
\hline
\end{tabular}

Sumber: Diolah dari data penelitian, 2021

Dari data statistik di atas, diketahui data variabel body dissatisfaction yang diperoleh dari responden mempunyai rata-rata 103,16 sedangkan simpangan baku 7,927, median sebesar 102,00, skor minimum 86 dan skor maksimum 122. Hal ini menunjukkan bahwa rata-rata body dissatisfaction dari responden termasuk cukup baik. Instrumen ini diperoleh dari hasil kuesioner 30 pernyataan. Skor simpangan baku 7,927 atau sama dengan $8,17 \%$ dari rata-rata, hal ini menunjukkan perbedaan nilai antara responden termasuk kecil. Hal ini menunjukkan bahwa data skor body dissatisfaction cukup beragam.

Tabel 4 Distribusi Frekuensi Body Dissatisfaction

\begin{tabular}{|c|c|c|c|c|c|}
\hline \multicolumn{6}{|c|}{ Body dissatisfaction } \\
\hline & & Frequency & Percent & Valid Percent & Cumulative Percent \\
\hline \multirow{23}{*}{ Valid } & 86 & 1 & 1.3 & 1.3 & 1.3 \\
\hline & 87 & 2 & 2.6 & 2.6 & 3.9 \\
\hline & 90 & 2 & 2.6 & 2.6 & 6.5 \\
\hline & 92 & 1 & 1.3 & 1.3 & 7.8 \\
\hline & 93 & 3 & 3.9 & 3.9 & 11.7 \\
\hline & 95 & 2 & 2.6 & 2.6 & 14.3 \\
\hline & 96 & 3 & 3.9 & 3.9 & 18.2 \\
\hline & 97 & 3 & 3.9 & 3.9 & 22.1 \\
\hline & 98 & 4 & 5.2 & 5.2 & 27.3 \\
\hline & 99 & 4 & 5.2 & 5.2 & 32.5 \\
\hline & 100 & 4 & 5.2 & 5.2 & 37.7 \\
\hline & 101 & 5 & 6.5 & 6.5 & 44.2 \\
\hline & 102 & 7 & 9.1 & 9.1 & 53.2 \\
\hline & 103 & 5 & 6.5 & 6.5 & 59.7 \\
\hline & 104 & 2 & 2.6 & 2.6 & 62.3 \\
\hline & 105 & 2 & 2.6 & 2.6 & 64.9 \\
\hline & 106 & 3 & 3.9 & 3.9 & 68.8 \\
\hline & 107 & 1 & 1.3 & 1.3 & 70.1 \\
\hline & 108 & 2 & 2.6 & 2.6 & 72.7 \\
\hline & 109 & 2 & 2.6 & 2.6 & 75.3 \\
\hline & 110 & 2 & 2.6 & 2.6 & 77.9 \\
\hline & 111 & 2 & 2.6 & 2.6 & 80.5 \\
\hline & 112 & 4 & 5.2 & 5.2 & 85.7 \\
\hline
\end{tabular}




\begin{tabular}{ccccc}
113 & 3 & 3.9 & 3.9 & 89.6 \\
114 & 1 & 1.3 & 1.3 & 90.9 \\
115 & 1 & 1.3 & 1.3 & 92.2 \\
116 & 3 & 3.9 & 3.9 & 96.1 \\
118 & 2 & 2.6 & 2.6 & 98.7 \\
122 & 1 & 1.3 & 1.3 & 100.0 \\
\hline Total & $\mathbf{7 7}$ & $\mathbf{1 0 0 . 0}$ & $\mathbf{1 0 0 . 0}$ \\
\hline
\end{tabular}

Sumber: Diolah dari data penelitian, 2021

Dari distribusi frekuensi juga dapat diketahui skor yang berada di atas rata-rata $53,2 \%$, sedangkan yang berada di bawah rata-rata $44,2 \%$ dengan demikian diartikan skor yang berada di atas rata-rata lebih banyak dibanding yang berada di bawah rata-rata, menunjukkan bahwa siswa yang mempunyai body dissatisfaction rendah, lebih banyak dibanding yang tinggi. Berdasarkan tabel distribusi dapat disimpulkan bahwa body dissatisfaction siswi kelas X dan XI SMK Mardi Bakti Jakarta Timur termasuk kategori rendah.

Data selanjutnya melalui pengujian SPSS 25. Menurut ketentuan yang ada pada program tersebut maka kriteria dari linieritas data adalah jika sig $>0,05$ maka hubungan kedua variabel membentuk garis linier. Berdasarkan hasil pengujian diperoleh nilai sig. sebesar 0,078. Hal ini berarti bahwa hubungan kedua variabel bersifat linier. Selanjutnya berdasarkan pengujian Anova diperoleh nilai sig. $=0,000$ dan fhitung $=15,068$ sedangkan $\mathrm{f}_{\text {tabel }}=3,967$, karena nilai sig. $<0,05$ dan fhitung $>\mathrm{f}_{\text {tabel }}$ maka $\mathrm{H}_{1}$ diterima yang berarti hipotesis diterima atau terdapat hubungan yang signifikan antara self-compassion dengan body dissatisfaction. Data dari hasil pengujian regresi tersebut dapat lihat bahwa terdapat pengaruh yang signifikan antara layanan informasi berbasis self-compassion terhadap body dissatisfaction.

\section{Simpulan}

Berdasarkan pembahasan diskusi hasil penelitian maka dapat disimpulkan bahwa selfcompassion (rasa berbelas kasih sayang terhadap diri sendiri) siswa perempuan SMK Mardi Bakti Jakarta Timur termasuk kategori cukup baik. Kemudian untuk kondisi body dissatisfaction (persepsi negatif terhadap bentuk tubuh diri sendiri) siswa perempuan SMK Mardi Bakti Jakarta Timur termasuk kategori cukup baik. Dimana terdapat pengaruh yang signifikan antara pemberian layanan informasi berbasis self-compassion untuk mereduksi body dissatisfaction pada siswa perempuan SMK Mardi Bakti Jakarta Timur. Layanan informasi berbasis self-compassion memberikan pengaruh sebesar 50,6\% dalam mereduksi body dissatisfaction yang dialami siswa perempuan di SMK Mardi Bakti Jakarta Timur. Hasil penelitian ini sangat penting untuk dapat terus dikembangkan oleh guru BK di sekolah dan juga oleh praktisi pendidikan untuk dapat membantu peserta didik terlebih khusus siswa perempuan yang pada saat ini banyak mengalami kondisi body dissatisfaction terutama dari perkembangan penggunaan media sosial yang banyak menampilkan kondisi ideal bentuk tubuh.

\section{Ucapan Terima Kasih}

Terima kasih kepada semua pihak yang telah membantu dalam pelaksanaan penelitian dan penulisan artikel di dalam jurnal ini, terutama Program Studi Bimbingan Konseling Universitas Indraprasta PGRI, kepada dosen pembimbing, pihak sekolah SMK Mardi Bakti Jakarta Timur yang telah membantu dalam melaksanakan penelitian, kedua orang tua, dan rekan-rekan seperjuangan. semoga Allah memberikan kebaikan yang berlipat kepada mereka 
yang telah memberikan bantuan, dan dapat menjadikan semua ini sebagai ladang di dalam beribadah.

\section{Daftar Rujukan}

Breines, J. G., \& Chen, S. (2012). Self-compassion increase self-improvement motivation. Personality and Social Psychology Bulletin, 38(9), 1133-1143.

Fitriyanti, E. (2018). Efektivitas layanan informasi terhadap sikap remaja mengenai obat PCC (paracetamol, cafein, dan carisoprodol). TERAPUTIK: Jurnal Bimbingan dan Konseling, 2(2), 102-108.

Fitriyanti, E., Dachmiati, S., \& Satrianta, H. (2017). Information services in counseling and locus of control toward communication between parents and childrens. TERAPUTIK: Jurnal Bimbingan dan Konseling, 1(2), 125-131.

Hasanah, F. A., \& Hidayati, F. (2017). Hubungan antara self-compassion dengan alienasi pada Remaja (Sebuah studi korelasi pada siswa SMK Negeri 1 Majalengka). Jurnal Empati, 5(4), 750-756.

Hidayati, D. S. (2016). Self compassion dan loneliness. Jurnal Ilmiah Psikologi Terapan, 3(1), 154164.

Jayanti, H. Y. (2020). Peramalan Pendapatan Reksa Dana Dalam Setahun Mnggunakan Metode Regresi Linier Sederhana. Jurnal Teknologi Informasi dan Komunikasi, 8(2).

Kurnia, Y. C., \& Lestari, S. (2020). Body dissatisfaction dan keterkaitannya dengan subjective well-being pada perempuan masa emerging adulthood. MEDIAPSI, 6(2), 86-93.

Kusumawati, P. D., Ragilia, S., Trisnawati, N. W., Larasati, N. C., Laorani, A., \& Soares, S. R. (2018). Edukasi Masa Pubertas pada Remaja. Journal of Community Engagement in Health, 1(1), 1-3.

Niide, T. K., Davis, J., Tse, A. M., Derauf, C., Harrigan, R. C., \& Yates, A. (2011). Body ideals and body dissatisfaction among a community sample of ethnically diverse adolescents on Kauai, Hawaii. Hawaii J Public Health, 3(1), 1-7.

Siswoaribowo, A., Taukhid, M., \& Paramita, D. (2020). Pengaruh Penerapan Self Affirmation Terhadap Penurunan Body Dissatisfaction Pada Remaja Akhir. JURNAL ILKES (Jurnal Ilmu Kesehatan), 11(2), 285-295.

Sureiman, O., \& Mangera, CM (2020). Uji-F signifikansi keseluruhan dalam analisis regresi disederhanakan. Jurnal Praktek Ilmu Kardiovaskular , 6 (2), 116.

Tariq, M., \& Ijaz, T. (2015). Development of body dissatisfaction scale for university students. Pakistan Journal of Psychological Research, 30(02), 305-322.

Yuanita, H. \& Sukamto, M. E. (2013). Fenomena body dissatisfaction pada perempuan anggota fitness centre. Jurnal Psikologi Teori E Terapan, 4(1), 12-23.

\section{Competing interests:}

The authors declare that they have no significant competing financial, professional or personal interests that might have influenced the performance or presentation of the work described in this manuscript. 